\title{
Lwah Inalih Haken, Arti Kiasan Atau Sebenarnya?
}

\author{
Baskoro Daru Tjahjono
}

nfn. Widianto

Keywords: inscription, Prambanan, location, river, interpretation

\section{How to Cite:}

Tjahjono, B. D., \& Widianto, nfn. Lwah Inalih Haken, Arti Kiasan Atau Sebenarnya?. Berkala Arkeologi, 14(2), 47-51. https:// doi.org/10.30883/jba.v14i2.642

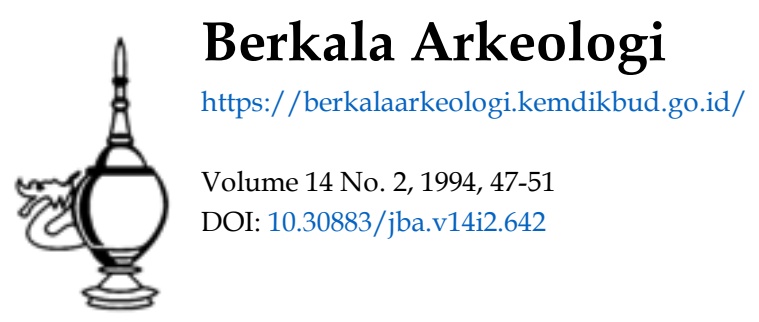

\section{(i) (2)}

This work is licensed under a Creative Commons Attribution-NonCommercial-ShareAlike 4.0 International License. 


\title{
LWAH INALIH HAKEN, ARTI KIASAN ATAU SEBENARNYA?
}

\author{
Baskoro D. Tjahjono * Widiyanto *
}

\section{Permasalahan}

Lwah inalih hakén adalah sepenggal kalimat yang terdapat dalam prasasti Ciwagrèha yang berarti sungai dipindahkan. Pemindahan aliran sungaı ini dilakukan karena tempat yang dilaiui sungai tersebut akan didirikan sebuah kompleks bangunan suci (candi). Bangunan suci yang dimaksud dalam prasasti Ciwagrèha tersebut oleh para ahli dikaitkan dengan kompleks Candi Rara Jonggrang di Prambanan. Memang yang paling sesuai dengan gugusan candi sepert uraian dalam prasast tersobut adalah Candi Rara Jonggrang. Jika ini benar berarti sungai yang dipindahkan alirannya adalah Sungai Opak yang terietak di sebelah barat candi. Permasalahannya, apakah dalam kenyataan Sungai Opak pemah mengalami pemindahan aliran sungai? Judul di atas muncul karena adanya kenyataan bahwa halaman ketiga dari kompleks Candi Rara Jonggrang temyata tidak konsentris sepert dua halaman lainnya, tetapi agak menyerong seolah-olah untuk. menghindari aliran sungai. Sehingga timbut pertanyaan apakah sebenamya yang dipindahkan itu sungalnya ataukah halaman ketiganya?

Ada dua ahli epigrafi yang menyebutkan adanya pemindahan aliran sungai itu berdasarkan terjemahan prasasti di atas, namun temydta berbeda dalam penaisıran. Casparis menyatakan bahwa setelah kompleks percandi-an itu selesai dibangun maka dialihkantah aliran sungai sehingga menyusun halaman candi. Sedangkan Boe. charı justru menyatakan sebaliknya, yartu sungai dipındahkan karena menyentuh halaman candi.

Kompleks Candi Rara Jonggrang memilikı tıga halaman, yaitu halaman I adalah halaman pusat atau halaman palıng suci, halaman if pada bagıan tengah, dan halaman III adalah halaman paling luar. Di sebelah barat candi mengalir Sungai Opak dan anak sungainya. Data empirik menunjukkan bahwa anak sungai Opak temyata mengalir melalui halaman III atau halaman paling ivar kompleks Candi Rara Jonggrang. Jadi ma. salahnya, jika benar ada pemindahan aliran sungal seperti yang disebutkan dalam prasasti Ciwagrèha, maka sungai mana yang dipindahkan? Dan untuk membuktikan pendapat Casparis atau. kah Boochan yang benar harus diketahui pada bagian mana aliran sungai yang dipindahkan itu?

Tujuan penulisan ini adalah dalam rangka mencari adanya gejala bekas pemindahan aliran sungai melalui analisis paleogeomortologi. Berdasarkan interpietass toto udara diharapkan tompak adanya gejala-gejala tersebut. Untuk mendapatkan kepastian adanya bekas alıran sungai yang dipindahkan harus diuji melalui penelitian lapangan, baik melalui ekskavas: maupun penerapan metode geolistnk.

\section{Beda Pendapat Penafsiran Prasasti Ciwa- grêha}

Prasast Ciwagrèha yang bertarikh 778 Saka atau 856 Masehi adaiah prasasti yang penting dan istimewa, karena selain memuat peristiwa sejarah yang sangat penting pada pertengahan abad IX Masehi juga terdapat uraian rinci tentang suatu gugusan candi. Dalam prasasti Ciwagrèha disebutkan bahwa pusat gugusan candi itu dikelilingi oleh tembok. Bangunan induk tersebut dikitari oleh bangunanbangunan kecil yang berderet bersap-sap dengan bentuk dan ukuran sama (Casparis, 1956: 310 11: Anom, 1993: 6.7). Gambaran gugusan candi seperti itu memang sesuai dengan keadaan kompleks Candi Rara Jonggrang

Prasasti Ciwagretra adalah prasast rang terkenal karena berhubungan dengan bangunan suci yang terkenal pula. Tentu para ahli terutama para epigraf sudah sangat paham akan isınya. Sehingga pembicaraan mengenai prasasto ini cenderung mengulang-ulang dan mungkin dıanggap sudah bası. Namun apabila dicermatı kembali, ada sesuatu yang masih mengganjal dan perlu untuk diungkap dan diluruskan, yaitu sebaris kalimat pada bart 25 baris b yang berbuny: "Lwah ya inalin hakèn apanryāniọ ik paimahan". Kalimat pendek tersebut sangat penting artinya karena menyangkut kepentingan pembangunan sebuah kompleks bangunan sucs. Hal yang dirasa masih mengganjal karena masih adanya beda pendapat di antara para ahti, khususnya Casparis dan Boechari, tentang tafsir kalimat di atas. Hingga saat ini beda pendapat tersebut masih berlangsung, karena tidakJ belum adanya upaya untuk membuktikan adanya pemindahan aliran sungai tersebut melalui kajian ilmu lain. Karena bertiubungan dengan perubahan aliran sungai, maka vang paling tepat adalah geomortologi, khususnya paleogo mortolog:

Beda pendapat antara Caspans dengan Boechari entang penafsiran kalımat diatas sebenarnya hanya terletak pada kata apan (Boechasi

\footnotetext{
- Star penetiti pada Balar Akeolog Yogyakarta

- Star pengajar pada Junsan Geugari Fisik. Fanutas Googofi. Unversitas Gadjan Mada
} 
1973 20;. Oien Casparis apan diartikan "sehıngga". sedangkan menurut Boechari berarti "karena". Dengan demikian "Lwah ya inaith haken apaniyanid ik patmahan", oleh Casparis diterjemahkan sebagai Tihe (course of the) river was changed so that it rippled along the grounds" Menurut Boechari, kalimat tersebut beraro "Maka dialihkanlah aliran sungainya karena menventuh haiaman candi".

Ada perbedaan mendasar mengenai dua pengertian tersobut, pengertian pertama berarti aliran sungai justru dimasukkan ke halaman candi, sedangkan pengertian kedua berarti aliran sungał dipindahkan keluar halaman candi. Dengan demikian jika pengertian pertama yang benar berart aliran sungai harus dibelokkan ke timur Jika pengestian kedua yang benar seharusnya sungai dibelokkan ke barat

\section{Proses Pendirian Bangunan Sucl}

Candi adalah bangunan suci tempat pemujaan Dewa. Hal ini telah ditegaskan oleh Soekmono dalam disertasinya yang berjudul Candi Fungsl dan Pengertiannya. Candi melambangkan Mahameru yaitu gunung yang menjadi pusat alam semesta. Bangunan can-dinya yang terdiri atas tıga bagian yaitu kaki, tubuh, dan atap candi melambangikan tiga dunia, yaitu bhurkoka, bhuwarloka, dan swarloka (Stutterheim, 1937:245; Boecnan, 1978 13!

Karena cand adalah bangunan sakral maka proses pendirsannya tentu tidak semudah orang mendirikan bangunan rumah tinggal (yang versifat profan). Ada syarat-syarat tertentu yang narus dipenuhi. Disebutkan dalam Kitab Mānasàra-Ciipaçastra, kitab yang berisı aturan-aturan pembangunan kull di india, bahwa sebelum suatu bangunan kııl didırikan maka arsitek pendeta (sthapaka) dan arsitek perencana (sthapati) harus lebih dahulu menilai kondisi dan kemampuan iahan yang akan dijadikan tempat berdirinya bangunan suci tersebut (Acharya, 1993.13-21 Kramrisch, 1946 3-17. Mundardjito, 1993. 13) Kitab tersebut juga menerangkan tentang teknikieknik untuk mengkajı calon lahan bangunan kuil, antara lain mengisi lubans uji dengan air untuk dinilaı derajat kemelesakannya, dan menebar bibit tanaman dipermukaan lahan yang sudah dibajak untuk dinilai tingkat kesuburannya. Dengan demikıan kitab tersebut menyatakan bahwa lahan tempat berdirinya suatu bangunan kuil dinılai sangat tinggi, bahkan lebih penting dari bangunan suci itu sendiri (Mundardjito, 1993: 239). Pentingnya lahan tempat pendinan bangunan kuli itu juga ditegaskan oieh Soekmono yang menyatakan bahwa: "Suatu tempat suci adalah sucı karena potensınya sendiri". Dengan demikıan sesungguhnya yang primer adalah tanahnya: sedangkan kuilnya hanyalah mendudukı tempat nomor dua (Soekmono, 1974: 330). Jadi menurut kitab tersebut ada dua hal penting dalam proses pendirian bangunan sucl, yaitu pemilihan lahan untuk pendiraan bangunan kuil dan pengujıan tanahnya.

Di Indonesia kitab (naskah Jawa Kuna) yang bensı aturan-aturan pendirian bangunan suci tidakl belum dijumpai, namun tampaknya aturan-aturan dalam pendirian suatu bangunan suci juga diterapkan di sıni. Petunjuk mengenai hal ini dinyatakan oleh Mundardjito bahwa dari hasif penelitian mengenai bentuk bangunan candi ukuran, gaya, serta kegunanan atau fungsinya dapat memberi petunjuk akan adanya keteraturan, yang mungkin dapat dijadikan pangkal tolak berpikir tentang adanya aturan umum yang dipakaı sebaga pedoman bagi orang masa lalu dalam rangka pembangunan candi (tertulis atau tidak testulis) (Mundardjito, 1993: 12).

Dalam pendirian candi titik pusat kompleks percandian menspakan titik yang sangat penting. sehıngga harus ditentukan lebih dahulu dengan perhitungan magis (Wheatley, 1971: Boechari, 1973: 13). Sebagai contoh disebutkan bahwo ttik pusat kompleks Candi Rara Jonggrang temyata tidak di pusat candi induknya tetapi di sudut selatan pipi tangga sebelah timur. Di sıni ada bangunan menara kecil yang di dalamnya berisı susunan tiga batu persogi dengan tanda silang d atasnya dan garis lurus ke bawah di sisinya, seolah-olah sengaja menunjukkan titik pusat halaman percandian

\section{Analisis Paleogeomorfologi Aliran Sungai Opak}

Sungai Opak terietak di antara sistem Sungai Dengkeng di sebelah timur dan sistem Sungai Gadjahwong di sebeiah barat Sungar Opak mengalir melałui Kota Prambanan. Sungai Dengkeng dengan sungai utamanya Sungai Woro atau Sungai Simping, bermula dari puncak Gunung api Merapi, begitu pula Sungaı Opak, dan Sungai Gadjahwong. Ketga sungai ini di bagıan puncak dipisahkan oieh perbukitan yang batuannya berasal dari kegiatan Merapi tua dengan batuan yang cukup kompak. Sungaı Gadjahwong, walaupun mengalir dan daeras puncak, namun teriındung oleh perbukitan tersebut.

Berdasarkan peta geomorfologi (JICA 1978), sebagian besar lereng selatan Gunungapı Merapi merupakan kıpas aluvial, yang terbentuk oleh piroklastik yang berasal dari Gunungaap; Merapi. Endapan piroklastik membentuk kipas aluvial mulaı dan ketinggian $350 \mathrm{~m}$, hingga ketınggian $140 \mathrm{~m}$. Tebal endapan piroklastik inı tidak merata antara satu tempat dengan tempa: lain, tergantung dari mortologi awal sebelum terjadi proses pengendapan yang membentuk kipas aluvial tersebut Pola pengendapan 
piroklastik yaitu tebal pada lembah sungai dan semakin tipis menjauhı lembah sungai

Lingkungan fisik Sistem Sungai Opak tidak teilepas dari aktivitas Gunungapi Merapl. Gunungaps Merapı merupakan gunungapı yang palıng aktif di Jawa. Menurut catatan sejarah kegiatan yang cukup hebat terladi pada tahun 1006 Kegiatan ini dimungkinkan berkaitan dengan terjadinya kerusakan dan penımbunan beberapa candi di sekitamya, misalnya Borobudur, Mendut, Pendem, Lumbung, dan Candi Asu, semuanya di iereng barat Gunungapi Merapi. Prambanan dan peninggalan sejarah di leseng selatan (Bemmelen, 1970), seperti yang dinyatakan oleh Verstap. pen. 1986, bahwa lereng selatan Gunungapi Merapi pemah dilanda aliran lahar, yang sebagian besar endapannya berupa pasir.

Widiyanto, 1992. dalam penelitian di DAS. Woro mendapatkan bahwa daerah Plumbon, Prambanan hingga sebelah barat Gondang pernah dilanda aliran lahar Endapan lahar ini berselang-seling dengan endapan fluvial. BemmeIen, 1953, menyatakan bahwa Gunungapı Merapi pernah meletus sangat besar pada tahun 1000. Kogiatan Gunungapı sebelum 1006 dinya-takan sebagai keglatan Gunungapi Merapi Tua, sedangkan kegratan setelah itu dinyatakan seba-gai kegiatan Gunungapi Merapi Muda. Dinyatakan oula bahwa sebagian besar peninggalan sejarah serasal darı sebelum abad $X$. kemudian ditemuKan lag! peninggalan sejarah pada abad XV. Antara abad $X$ hıngga abad XV sangat langka peninggalan sejarah di sekitar Merapi. Ini dimungkınkan karena pengaruh bencana Merapi pada abad $X$ yang maha dahsyat Curah hujan yang unggi di daerah Merapi menyebabkan tersangkutnya endapan piroklastik pada lereng atas. seianjutnya terjadi banjir lahar sangat besar (Labuerton, 1922, pada Bemmelen, 1971)

Menurut pola aliran di Sungai Opak dapat dibedakan menjadi tıga penggal, yaitu penggal atas, terietak di bagıan hulu Tamanan, penggal tengah terletak antara Tamanan dengan Daerah Boko, dan penggal bawah terietak di bagian hilir Boko Tiga penggal sungai tersebut memberikan kenampakan yang karakteristik yaitu penggal atas dengan pola memussit. Terjadinya pola ini disebabkan oleh adanya bottle neck di daerah Tamanan. Aliran yang semula menyebar kemudian menuju satu arah. Penggal tengah. mem. punyar pola saluran yang lurus, merupakan satu tubuh sungas. Penggal tengah ins terhalang ofeh Perbukitan Boko, sehingga berbelok ke barat Begitu pula Sistem Sungai Dengkeng, karena terhalang perbukitan kemudian berbelok ke timur Penggal bawah, terletak di hilir daerah Boko. Penggai inı dicinkan oleh aliran yang membentuk meander karena daerahnya cukup datar
Dalam kaltannya dengan pengangkutan material piroklastik penggal atas merupakan sumber materia!, penggal tengah merupakan penggal transportasi, dan penggal bawah meru. pakan penggai sedimentasi. Penggal atas dapat memberikan material yang terangkut oleh aliran air pada musim penghujan, namun penggal transportasi terganggu oleh adanya batuan kompak kelanjutan Perbukitan Boko yang terdapat bagian baratnya. Akibat gangguan batuan in menjadikan aliran piroklastik tidak dapat lancar dan sebagian diendapkan pada penggal tengah di dekat Prambanan Oleh karena itu endapan piroklastik di daerah tersebut sangat tebal

Ditinjau dari pola saluran Sungai Opak ds daerah Prambanan, didapatkan adanya pembelokan sungai ke barat dengan pola saluran yang lurus. Saluran yang lurus ini sepanjang $1 \mathrm{~km}$. kemudian berbelok ke timur sepanjang $0.5 \mathrm{~km}$ dan akhirnya kembali berbelok ke barat membentuk sungai bermeander Ditınjau dan pola tersebut, kemungkınan besar yang berpengaruh adalah campur tangan manusia, mengıngat batu an di daerah tersebut adalah endapan material lepas yang berasal dan Gunungapi Merapi.

Dalam kaitannya dengan pola saluran Sungai Opak sebelum 1006, yaitu sebelum terjadi pengendapan lahar yang menutup sebagian besar sistem Sungai Gadjahwong Sungaı Opak, dan Sungaı Woro, sistem sungai yang terbentuk sekarang mempunyal pola yang serupa. Oleh karena itu dimungkinkan pula pengaruh aktivitas manusia sebelum iD06 mempengaruhi bentuk saluran yang ada sekarang, yaitu terjadinya pembelokan alıran Sungai Opak di sebelah utara kompleks candi dan di sebelah selartan rel kereta apı

Untuk menelusur kedudukan dan pengarun campur tangan manusia dalam merubah arah aliran Sungai Opak dapat dilakukan dengan penelusuran pola sebaran batuan di Jaeran tersebut dengan pendekatan geolistrik mengingat jika dilakukan dengan exskavasi membutuhkan dana yang sangat besar dan kemungkinan lahan di daerah tersebut telah digunakan untuk berbagai keperiuan

\section{Kesimpulan}

Dari kitab yang berisı aturan-aturan pendirıan bangunan sucı dan india vartu ManasaraCilpaçastra dapat dıketahuı bahwa lokası pendirian bangunari suc sangat penting, bankan iebih penting dari bangunannya sendirl Aturanaturan tersebut walaupun tidak dıjumpai dalam naskah-naskah Jawa Kuna tampaknya juga diterapkan dalam pendinan cands-cands di Indonesia. Hal ini telah dibuktikan oieh Mundarjito dalam penelitian terhadap penempatan situs-sıtus candi di daerah Yogyakarto Secara tegas dinyatakan 
Dahwa pemilihan lokası yang dikaıtkan dengan pertimbangan-pertimbangan ekologis sangat penting Disamping itu bag! suatu bangunan sucl penetuan utik pusat sangat penting. Penentuan trik pusat in dilakukain melalui perhitungan magis, sehingga kemungkinan letaknya tepat di tengah sungai

Dengan pengetahuan akan pentingnya tokası dan titik pusat suatu bangunan suci, maka rampaknya benar apa jang diuraikan dalam prasasti Çiwagrèha tentang Lwah inalah hakèn Pendapat tersebut emyata didukung oleh data paleogeomorfologi. Melalui analisis paleogeomorfologi dapat diketahui adanya tiga pola aliran sungai Opak, yang terdiri atas penggal atas, penggal tengah, dan penggal bawah. Pada penggal tengah tampak adanya pola saluran Wris, yang diperkırakan adanya campur tangan manusia. Melalui pengamatan paleogeomorfologi ternyata sistem sungai Opak yang terbentuk sekarang mempunyal pola yang serupa dengan sistem sungal sebelum terjadinya pengendapan ahar tahun 1006 . Dengan adanya pembelokan sungar ke barat dengan pola saluran lusus sepanjang $1 \mathrm{~km}$ kemudian berbelok ke timur sepanjang $0.5 \mathrm{Km}$, dan kembalı berbelok ke barat membentuk sungal bermeander tersebut tampakriya untuk. sementara pendapat Boechari rentang pemindahan airan sungai adalah benar. Untuk mendapatkan kepastian akan kebenaran pendapat Boechan tersebut harus diuji melalui peneittian iapangan Dengan penelusuran pola sebaian batuan meialus pendekatan geolistrik k.sanya merupakan aitematif bagi penelitian apangan dengan bıaya relatif lebıh murah dicanding ekskavas।

\section{KEPUSTAKAAN}

Mcharya Prasanna Kumar 1933. Architecture of Manasara London Oxford University Press

Anom, C M 1993 Candi Wahana, Pelestarian dan Pemantaatan. Departemen Pendidikan dan Kebudayazn Direktorat Jenderal Keoudayaan. Panitia Pemugaran Candı Wahana Candr Rara Jonggrang Pramoanan Daerah Istimewa Yogyakarta

Bemmelen RW van 1970 The Geology of indonesıa. Vol. 1A. The Hague. (cetak ulang)

1971 Four votcanic Outbursts inat influenced Human History Toba, Sunda, Merap! and Thera Reprinted From The Acta of The ist international Scientific
Congress on The Volcano of Thera. Held in Greece $15^{\text {th }}-23^{\text {rd }}$ September 1969. Athens

Boechan. 1978. Bahan Kajsan Arkeologr untuk Pengajaran Sejarah. Majalah Arkeologi. Th. II. No. 1. September.

Casparis, J.G. de. 1950. Selected inscription from The $7^{\text {th }}$ to The $g^{\text {th }}$ Century A.O. Prasast Indonesia II. Bandung: Masa Baru.

JICA (Japan International Cooperation Agency') 1978. Geomorphological Maps of Merapi Volcano. Tokyo.

Kramrisch, Stella 1946. The Hindu Temple Calcutta: University of Calcutta

Mundardjito. 1993. Pertimbangan Ekologi dalam Penempatan Situs Masa Hindu-Buda di Daerah Yogyakarta: Kajian ArkeologiRuang Skala Makro. (Rıngkasan) Disertasi. Universitas indonesıa. Jakarta

Soekmono 1974. Candi, Fungsi dan Pengertiannya Disertasi. Universitas Indonesia. Jakarta

Stutterheim, W.F. 1937 He Zinrijke Waterwerk van Djalatcenda. T.B.G. LXVil. him. 173 216.

Wheatley, P 1971. The Prvot of the Four Quarters. A preliminary enquiry into the origins and character of the ancient Chinese City. Edınburgh

Widtyanto 1992. Persebaran Lahan di Daerah Aliran Sungai Woro. Kiaten. Fakultas Geografi UGM Yogyakarta 


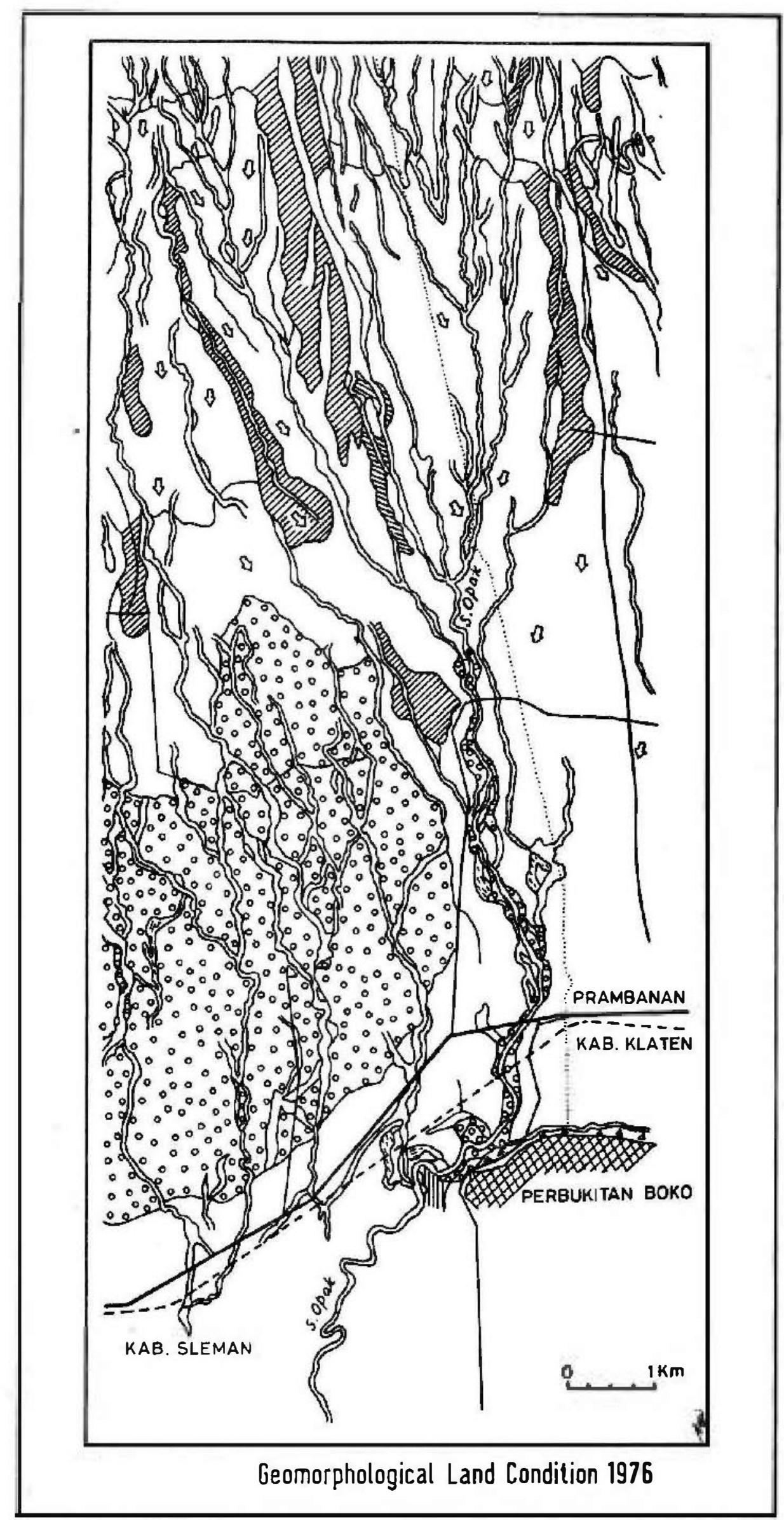

